\title{
IMPACTS OF DIFFERENT PHYSICAL ENVIRONMENTS ON CHILDREN'S PLAYING FIELD PERCEPTION
}

\author{
Merve Güroğlu ${ }^{1 \star}$ and Deniz Erinsel Önder ${ }^{2}$ \\ ${ }^{1}$ M.Sc. Student, Yıldız Technical University, Turkey, merveguroglu@gmail.com \\ ${ }^{2}$ Prof. Dr., Yıldız Technical University, Turkey, erinselonder@gmail.com \\ ${ }^{*}$ Corresponding author
}

\begin{abstract}
Perception is the process of acquiring information from the environment. The concept of perception explains the relationship of humans with the environment, and it is shaped by several different stimuli, such as the social, cultural, and physical environments. Children's perception is different from that of adults, and it develops gradually through the cognitive development periods of childhood. Children have had very little experience of the fast-changing environment around them, and thus they should grow in their own natural rhythm to become a part of society. To achieve this, children need time and places in which they can explore their environment by playing to improve their cognitive processes. The most important thing in a child's life is playing games. As long as a child plays games, he explores himself and his environment, and thus achieves satisfaction. In this way, the child finds the opportunity to acquire perceptual, cognitive, physical, and social gains, and he forms his spatial imagery through the stimuli that he gets from the environment.

In the past, children played freely in the traditional neighborhoods; they could make their own playing fields in dead-end streets and could explore nature and themselves through games. However, today, children in big cities are confined to playing under their parents' supervision and within a limited time period. Indoor places have replaced children's natural playing fields. With the increasing traffic and crime rate, children cannot explore their environment, nor can they play in front of their houses, on the sidewalk, or the street. However, the importance of the environment, in which the child lives, is great on his physical and social development. The more a child becomes integrated with his environment, the more he develops his environmental perception by finding opportunities to explore his environment and himself. This study aims to determine the way in which living in the countryside or in a big city affects children's perception of playing fields, and how this affects their use of these spaces. To achieve this, surveys were conducted with children living in different physical environments; by getting the children to draw pictures, we enabled them to transfer their mental schema onto the paper. The results of this study indicate that children's playing field perception varies according to the different stimuli presented in rural and urban areas. It is also shown that the spatial imagery formed by children is different as a result of this difference in perception. Moreover, it can be determined that children are influenced by the advantages and disadvantages of the environment that they live in. It is seen that negative factors, such as the increasing vehicle traffic and crime rates in big cities, have
\end{abstract}


an impact on the selection of playing fields. The information obtained from this study is intended to improve design decisions regarding the areas children use for playing, which have a significant role in their development. The study also aims to find solutions that will meet the expectations of children in these places.

Keywords: Child, play, playing field, perception, space imagery, cognitive development.

\section{INTRODUCTION}

Games contribute to children's physical, social, and emotional development. The child discovers both himself and the environment in which he lives because of games; he becomes integrated with that environment and acquires social skills. Wherever there is a child, there is a game; the child plays games on every occasion and in every place. The concept of playing is an element that affects the child's entire life (Ormanlıoğlu Uluğ, 2013, pp.14-15). Norsworthy and Whitley described the effects of games in a child's life by saying, "A child who does not play games not only misses the joy of being a child, but he cannot become a well-developed adult either" (Norsworthy and Whitley, 1937, p.132).

However, today's children live in a world that is constructed and framed in such a way that it is difficult to find an opportunity to play games. Families are worried about their children going out alone, and many children cannot even walk in the garden of their house without the company of an adult. As a result, many children spend their free time on indoor activities in front of the TV or a computer (White and Stoecklin, 1998). In the past, children had the chance to experience life by using their street, garden, green areas, and open-air spaces in the city. As these places no longer exist and crimes against children have increased, a child cannot feel comfortable anywhere. Free spaces and parks in the cities have been turned into industrial areas or high-rise buildings. The populations of the cities have increased and become heterogeneous. Walkways have been turned into streets due to the increasing number of vehicles, and cars and criminals have become a nightmare for children. Moreover, children cannot play on the pavements that they once used for playing games, because pavements have been used to solve the parking problem (Öymen Gür and Zorlu, 2002, p.9). The street has become a forbidden zone for children who live in the cities. There are now a number of obstacles between the child and his environment, and he cannot experience the street without an adult's permission. It has become impossible for children to play ball games in the street or to pick fruits from the trees in their neighbor's garden (Şahin,1989, pp.23-27).

This study discusses how the condition that children live in, i.e., an urban or a rural area, affects their perception of playing fields and how they use them. It examines which fields are used by children for playing games and how their perception of playing fields changes according to whether they live in an urban or a rural area, by means of a survey that includes open- and closed-ended questions and a mental mapping method.

This study is important in that it aims to contribute to further studies that aim to raise environmentally conscious, self-confident, and happy individuals with fully developed social skills. To achieve this, suitable playing fields can be created by defining the places that children use for playing, creating more opportunities for games, and implementing the necessary safety measures.

\section{LITERATURE REVIEW}

\subsection{The Concept Of Perception, Perceiving, And Cognition}

Perception is the process of becoming informed about or by the environment. The concept of perception helps us to understand the relationship between human beings and the physical environment, and it enables us to learn about that environment (Ünlü, 1998, p.5). Perceiving is the process of receiving information from outside, and it varies from one person to another according to their perception system, personality, social group, culture, and environment (Erkman, 1982, pp.46,47). The concept of perception is mostly associated with cognition. Cognition refers to the spatial meaning of objects, their symbolization, and understanding their original features. Cognition deals with mental qualities rather than perceptional ones. The basic difference between perceptional and cognitive processes can be clearly defined as follows: we see the world as flat on the perceptional level, despite knowing that it is orbicular on the cognitive level (Ünlü, 1998, p.22).

Studies have shown that children's perception is different from that of adults. Piaget analyzes children's perceptional-cognitive development in four main stages according to their age; children behave in a way that is unique to their developmental stage. Senses, perception, and instinct are dominant in the first two stages. In the latter two stages, the child who can think operationally is able to behave by using cognitive intuitions 
(Ertürk, 1992, p.22). The most important feature of these stages is that they follow one another in a definite order, and each stage is constructed on the previous one. These stages can be summarized as follows:

\subsubsection{Sensorimotor Stage (0-2 years)}

At this stage, the child cannot perceive the permanence of the objects that he sees around himself (Çanakçıoğlu, 2012, p.77) He behaves in a way that can be seen as involuntary, while trying to grasp a toy that he perceives as color and shape. His brain cannot properly determine the distance and direction between the object and his hand. It is quite difficult for the child to understand spatial relations (Öymen Gür and Zorlu, 2002, p.14)

\subsubsection{Preoperational Stage (2-7 years)}

The child talks about objects that are not in his field of perception. However, relations between the pieces that form the total object are randomly found. Information that is gained on the perceptional level cannot be well preserved on the cognitive level. That is, the mouth, which should be under the nose, may be drawn as being above it in a portrait. Euclidean relations such as ratio, distance, repetition, continuity, rhythm, and also the concept of perspective are neglected (Öymen Gür and Zorlu, 2002, p.14). At this stage, the child lacks the abilities of conservation or reverse thinking. He perceives objects as a whole without focusing on the details, and creates relations between the objects and concepts that have no connection. The child's concepts of quantity, time, and size are primitive. At this stage, the child cannot make cognitive comparisons yet (Yavuzer, 2015a, pp.84-86).

\subsubsection{Concrete Operational Stage (7-12 years)}

This is a milestone in terms of the child's cognitive development. He starts to think logically, grow out of egocentrism, and accept that other people's ideas may also be correct (Çanakçıoğlu, 2012, p.77). Children start developing concepts such as quantity, time, size, volume, and distance. At this stage, the child can understand the principle of conservation and classify objects according to different features. However, abstract thought is not completely developed at this stage (Yavuzer, 2015a, p.110).

\subsubsection{Formal Operational Stage (12 years - adult)}

The child can make assumptions and come to logical conclusions at this stage. He can systematically solve complicated problems that are presented in both concrete and abstract ways (Yavuzer, 2015a, pp.266,267).

\subsection{Children's Space Perception}

Piaget analyzed the concept of space according to the topics of topological, projective, and Euclidean space relations. Piaget and Inhelder argued that topological space is mentally reconstructed, which is followed by metrical and projective concepts (Piaget and Inhelder, 1956, p.45).

\subsubsection{Topological Space Relations}

Topological space includes proximity, separation, order, enclosure, and continuity relations. Before the child develops projective and Euclidean space relations, he starts to develop primary relations such as proximity, separation, order, and enclosure. These topological relations are accepted as forming the basis for the concept of space. Proximity is the most basic space relation that can be understood with perception. It is the proximity of items that belong to the same perceptional space from one to another. Separation is the act of separating two neighboring items from one another. Order is listing one of the two neighboring items before the other. Enclosure is defined as one item being enclosed by another on a two-dimensional level and an object being in a closed box on a three-dimensional level. Continuity is the continuity of items without interruption. An expression of perspective, a reference system, a dimension, or the conservation of distance cannot be seen within topological space relations (Piaget and Inhelder, 1956, pp.6-8,447,476).

\subsubsection{Projective Space Relation}

While topological relations deal with the features of the objects, projective space relations deal with extensive relations of the objects from different perspectives. There is more than one reference system involved in projective space relations. Projective space relations include the shape of the objects, their position in relation to each other, the distance between them, and perspective. At first, the child's perspective expressions may appear weird, such as when the child draws different perspectives in the same picture (Piaget and Inhelder, 1956, pp.375, 474-476).

\subsubsection{Euclidean Space Relation}

Euclidean space relations, which are based on one reference system, are formed with the development of 
complicated perspectives. The development of this system is completed by making connections between different objects and putting all these objects in an order (Piaget and Inhelder, 1956, pp.375,418). The child understands that the representation of objects can differ according to different reference situations. In this way, he starts to express the relations between objects with correct perspective rules by comprehending that the objects that are closer to the reference point look bigger and vice versa (Çanakçıoglu, 2012, p.79).

\subsection{Cognitive Map}

According to Lynch, cognitive maps are images that a person develops about a place. Environmental images are two-way processes between the observer and the environment. The environment reveals differences and relations. While people are constructing images, they choose, organize, and understand what they see through their aims and observations. Lynch analyzed city images under five topics of paths, edges, districts, nodes, and landmarks. Paths are areas such as roads, pavements, transportation areas, and railways that people use within the extent of their habits and opportunities. Edges are linear elements that are not used for transportation, and thus they are borders between two places. Shores, railways, and walls can be given as examples of edges. Districts are perceived as two-dimensional areas, and they constitute parts of the city. Nodes are intensive focal points that a person uses while going from one place to another. Landmarks form reference points and most of the time they are physical elements such as buildings, signs, or stores (Lynch, 2013, pp.7,51-53).

Individual differences in the cognitive map are considered to be a significant factor. Factors such as personal experiences, type of transport used, gender, age, residence, and occupation create differences in cognitive maps (Ünlü, 1998, p.27).

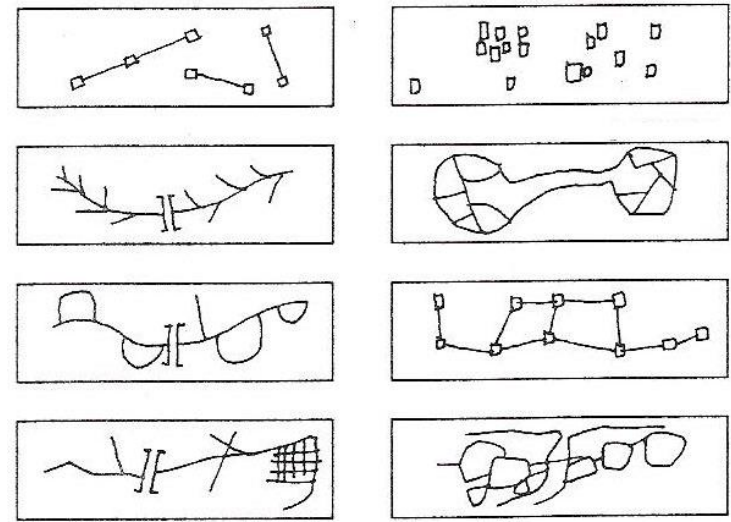

Fig 1. Individual differences in the cognitive maps (Appleyard, 1970).

\subsection{The Fields Most Used by Children for Playing Games}

The fields that children use the most can be analyzed in terms of four main topics: house, environment around the house, school, and playground.

\subsubsection{House (Home)}

The house is an important concept for the child. It represents security, family sincerity, and guarantees life, order, and shelter for him. Although there are many different houses, the only house that matters for the child is his own house. The concept of house is at the heart of the child's subconscious and emotional world (Yavuzer, 2015b, p.68). The child builds his first relations with the world at home (Ertürk, 1992, p.23).

\subsubsection{Environment around the House}

Streets, apartment hallways, entrances, front yards, backyards, and pavements can be listed as the environment around the house. Those places in which the child can play outdoor games are the most sought after. Studies have shown that doorsteps, garden walls, pavements, and street surfaces can function as playing fields that make it possible to play different types of games.

Public places such as streets, pavements, squares, or even parking areas, are essential playing fields in all cultures and at all ages. Streets are places that make it possible for children to meet their friends and get to know each other and their adult neighbors. Streets give children the opportunity to socialize by finding playmates (Erkonak Aydemir, 2004, p.304). Playing on the street plays an important role in the child's physical, cognitive, social and emotional development (Abu-Gazzeh, 1998, pp.799-831). A well-kept garden or places within the scope of calling and seeing make it possible for them to encounter nature and engage in 
cognitive, creative, and imaginative activities (Öymen Gür and Zorlu, 2002, p.22).

\subsubsection{School}

Schools can be easily internalized from the very early ages, and they form the experiences and group of images that children keep with themselves throughout their lives. They offer children the opportunity to interact with the space outside their own gardens (Ciravoğlu, 2004, p.38). School gardens meet the children's need for playing games, giving them the chance to experience green spaces. They are important as they meet children's need to play outdoor games. Especially in the cities, where open spaces are diminishing, children grow without having the opportunity to play, which is very important for their development. Therefore, one of the most important aims of school gardens is that they meet children's need for playing (Volkan Aksu and Demirel, 2011, pp.40,41).

\subsubsection{Playground}

Playgrounds for children are open spaces that are organized according to particular types of games, isolated from the outer environment, and have definite traditional features. Traditional parks include fixed equipments. Swings, slides, ladders, crampons, palanquins, and sandpits are essential components of traditional playing fields (Öymen Gür and Zorlu, 2002, pp.172,268). Playgrounds not only offer green spaces, but they also play an important role in children's development (Yılmaz and Bulut, 2002, pp.346,347). They enable children to get to know nature and discover it. Their location, being closer to residential areas and further from crowded places or traffic, means that children can have the opportunity to play in safety. Wellorganized playgrounds make it possible for children to gather together and play freely (Duman and Koçak, 2013, pp.66,67).

\subsection{Children and Games}

A child is supposed to play games, just as an adult is supposed to perform particular activities during the day. A child's game-playing is as important as an adult's work. While adults earn a living by working, children develop their personality, skills, and intelligence by playing games. We can even say that games are a child's work. They help the child to learn about himself, other people, and the environment. Thanks to them, the child develops interests. The child who has discovered and developed his interests can apply them to his life, and thus he can be happy and successful in his private life and at work. Any place can be a playing field for the child. Providing a playing field for the child is much more important than giving him expensive toys (Ormanlıoğlu Uluğ, 2013, pp.13-15). Games are universal. Although the types of the games and the instruments used may vary, the term "game" continues to remain constant. Researches have shown that children who are not allowed to play games have some physical and social problems (Koçyiğit and Tuğluk, 2007, p.327). Experiences that a person has in his childhood are the keys to his role in adulthood. Playing games is the most effective way of developing intelligence. The child learns how to think, cooperate, share, make decisions, obey the rules, and take responsibilities. Games enable children to focus their attention on a point, use their skills, and get to know themselves. By playing games, the child has the opportunity to get rid of the aggressive instinct, which is one of the strongest instincts. Thanks to games, he minimizes the negative thoughts that he has during the day, expresses his emotions and needs, understands that he has to obey the rules, knows himself, and develops his skills. Games make children develop themselves in physical, perceptional, social, and emotional ways. Active games that affect children's muscle development give them the opportunity to discharge their energy. If this energy is not discharged, the child can become neurotic, shy, and touchy. He learns the concepts of color, size, and meaning with differently shaped and sized game materials. The child who plays games with his friends learns how to cooperate, obey the rules of communal life, get on with other people, and interact with them. He socializes through games and gains awareness of "me" and "others" (Yavuzer, 2015a, pp.175-183).

\section{OBJECTIVE AND METHOD}

Children's perception of playing fields, factors that affect the opportunities that they have to play, and how they change according to their living spaces are important, as this information allows us to take precautionary measures. In this way, policies that foster children's need to play games freely in a secure place can be developed. Hence, the following questions were intended to be answered in order to determine children's use of playing fields and their opinions on them.

Can children go out alone to play games?

Do they feel worried while they are playing outside? If yes, what are those concerns?

Where do children mostly play? 
Do the children's perceptions about playing fields differ according to where they live?

For the method of the study, a questionnaire and drawings have been used. Pictures are accepted as children's expressions of the environment around them and their perceptional skills. The child interprets the world according to how he perceives it, and he tries to depict it with drawings and expressions (Yavuzer, $2015 \mathrm{~b}, \mathrm{p}$.12). The sample of this study was restricted to the fourth grade students of a primary school in Bağcılar-İstanbul as the urban area, and a primary school in Alpullu village of Babaeski district in Kırklareli as the rural area. The reason why fourth grade students were chosen is that they are at the stage of developing perceptional-cognitive processes. According to Piaget, the child at this stage can think logically and understand the concepts of quantity, time, space, dimension, volume, and distance. The children were asked to draw the places that they mostly used as playing fields. This method aimed to identify which places they used as playing fields and what signs they perceived regarding those fields. In the first part of the questionnaire, the children were asked socio-demographic questions and questions about the type of the house that they lived in. The second part contained both open- and closed-ended questions that asked about the children's playing activities, whether they could go out alone or not, and the concerns that they had while playing outside. The participants comprised 50 children, 25 from each school, who were enrolled in the research. Equal numbers of students were chosen from each school for the comparisons to be reliable.

\section{FINDINGS AND DISCUSSION}

\subsection{Results of the Questionnaire}

The participants enrolled in this study comprised $58 \%$ females and $42 \%$ males.Out of these, $88 \%$ who lived in the city lived in an apartment, while $12 \%$ of them lived in a detached house; $84 \%$ who lived in the countryside lived in a detached house, while $8 \%$ of them in a dwelling house, and $8 \%$ of them lived in an apartment. While $100 \%$ of the children who lived in rural areas lived in a house with a garden; however, this ratio was $8 \%$ in urban areas.

Table 1. The condition of being worried while playing outside

\begin{tabular}{|c|c|c|c|c|}
\hline \multirow{2}{*}{ Answers } & \multicolumn{2}{|c|}{ Rural } & \multicolumn{2}{c|}{ Urban } \\
\cline { 2 - 5 } & $\begin{array}{c}\text { Number of } \\
\text { People }\end{array}$ & $\%$ & $\begin{array}{c}\text { Number of } \\
\text { People }\end{array}$ & $\%$ \\
\hline Yes & 3 & 12 & 20 & 80 \\
\hline No & 22 & 88 & 5 & 20 \\
\hline Total & 25 & 100 & 25 & 100 \\
\hline
\end{tabular}

While $88 \%$ of the children who lived in rural areas said that they did not feel worried while playing outside, $80 \%$ of the children who lived in urban areas said that they felt worried. The American Podiatric Association suggests that children should play outside as much as they can to grow in a healthy way. Playing outside assists children in becoming physically active by preventing obesity and improving their skeleton and musculature and allows them to develop mentally and enabes them to achieve high academic success (Tandon and Zhou, 2012, p.707).

Table 2. Level of Concern

\begin{tabular}{|c|c|c|c|c|}
\hline \multirow{2}{*}{ Level of Concern } & \multicolumn{2}{|c|}{ Rural } & \multicolumn{2}{c|}{ Urban } \\
\cline { 2 - 5 } & $\begin{array}{c}\text { Number of } \\
\text { People }\end{array}$ & $\%$ & $\begin{array}{c}\text { Number of } \\
\text { People }\end{array}$ & $\%$ \\
\hline People with bad intentions & 3 & 12 & 14 & 56 \\
\hline Cars & 0 & 0 & 9 & 36 \\
\hline Getting lost & 0 & 0 & 2 & 8 \\
\hline Constructions & 0 & 0 & 2 & 8 \\
\hline Falling and Hurting Oneself & 0 & 0 & 1 & 4 \\
\hline Total & 25 & 100 & 25 & 100 \\
\hline
\end{tabular}

Only $12 \%$ of the children who lived in the rural area said that they were worried about people with bad 
intentions. However, this concern was the top one among the children who lived in the urban area, with $56 \%$. Furthermore, $36 \%$ of the children who lived in the city said that they were worried about cars; $8 \%$ of them were worried about getting lost and construction sites. While children who lived in the city were worried about such negative elements as these, children who lived in the countryside did not have these kinds of concerns.

Urbanization and industrialization have detached nature from chidren's lives in various ways. One of these factors is vehicle density. Areas that were once places where animals roamed free, plants existed, and games were played, are now motorways or built-up areas. Now there are very few open spaces in densely populated residential areas in the cities. Moreover, disruptive social conditions, such as homelessness, crime, drug addiction, and gun use have made it dangerous to play games outside (Rivkin, 1997, pp.61-67).

Table 3. The ratio of children's opportunity to go out to play games without the company of an adult

\begin{tabular}{|c|c|c|c|c|}
\hline \multirow{2}{*}{ Answers } & \multicolumn{2}{|c|}{ Rural } & \multicolumn{2}{c|}{ Urban } \\
\cline { 2 - 5 } & $\begin{array}{c}\text { Number Of } \\
\text { People }\end{array}$ & $\%$ & $\begin{array}{c}\text { Number Of } \\
\text { People }\end{array}$ & $\%$ \\
\hline Yes & 25 & 100 & 20 & 80 \\
\hline No & 0 & 0 & 5 & 20 \\
\hline Total & 25 & 100 & 25 & 100 \\
\hline
\end{tabular}

While $100 \%$ of the children who lived in rural areas said that they could play outside without the company of an adult, this ratio fell to $80 \%$ in urban areas. It can be seen that $20 \%$ of the children who lived in urban areas could not play outside without the company of an adult. It can thus be said that children who live in urban areas have less opportunity to play outside because of their safety concerns, and their outdoor spaces to play in are limited today.

\subsection{Analysis of the Pictures}

Table 4. Center of Space in the Drawings

\begin{tabular}{|c|c|c|c|c|}
\hline \multirow{2}{*}{ Center of Space } & \multicolumn{2}{|c|}{ Rural } & \multicolumn{2}{c|}{ Urban } \\
\cline { 2 - 5 } & $\begin{array}{c}\text { Number Of } \\
\text { People }\end{array}$ & $\%$ & $\begin{array}{c}\text { Number Of } \\
\text { People }\end{array}$ & $\%$ \\
\hline Outdoor Focused & 24 & 96 & 19 & 76 \\
\hline Indoor Focused & 0 & 0 & 2 & 8 \\
\hline Both Indoor and Outdoor Focused & 1 & 4 & 4 & 16 \\
\hline Total & 25 & 100 & 25 & 100 \\
\hline
\end{tabular}

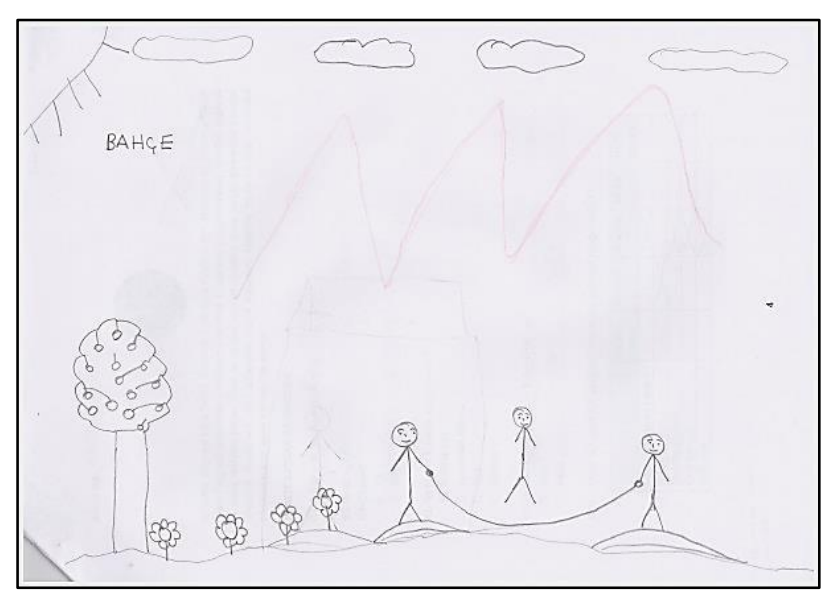

(a)

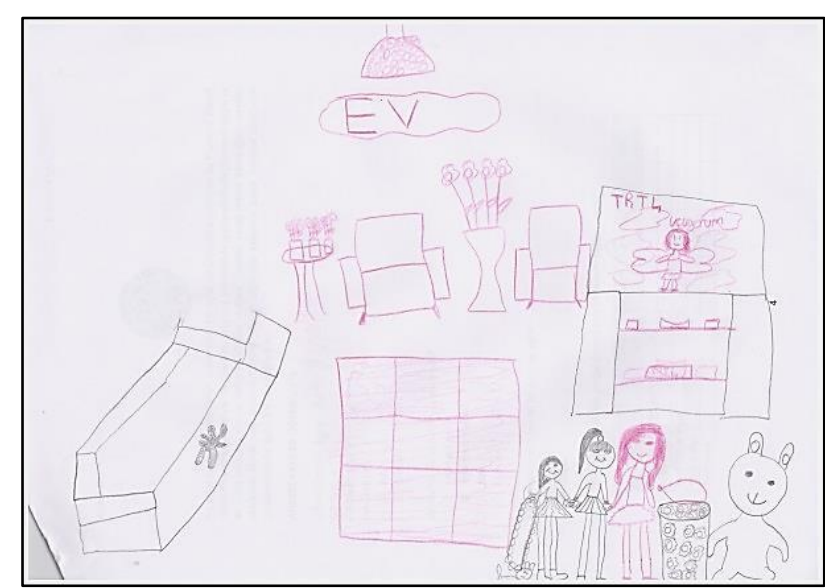

(b)

Fig. 1. Children's Drawings, (a) Rural (b) Urban 
Table 5. Places Drawn in the Pictures

\begin{tabular}{|c|c|c|c|c|c|}
\hline \multirow{2}{*}{ Places } & \multicolumn{2}{|c|}{ Rural } & \multicolumn{2}{c|}{ Urban } & Total \\
\cline { 2 - 6 } & $\begin{array}{c}\text { Number Of } \\
\text { Drawing }\end{array}$ & $\%$ & $\begin{array}{c}\text { Number Of } \\
\text { Drawing }\end{array}$ & $\%$ & $\%$ \\
\hline Playground & 14 & 56 & 13 & 52 & 54 \\
\hline Street & 4 & 16 & 15 & 60 & 38 \\
\hline Garden of the House & 9 & 36 & 1 & 4 & 20 \\
\hline Inside the House & 1 & 4 & 6 & 24 & 14 \\
\hline Total & 25 & 100 & 25 & 100 & 100 \\
\hline
\end{tabular}

As can be seen from Tables 5 and 6 , children mostly drew outer spaces as playing fields. Playgrounds and streets were mostly drawn as fields, with the ratios of $54 \%$ and $38 \%$ by children from rural and urban areas respectively. The garden of the house was the second most frequently drawn field by children from the countryside. It can be seen that the garden of the house was used more than streets in rural areas. Moreover, the house was used more as a playing field in the urban area when compared with the countryside. The reason for this might be that children in the rural area can play safely in the garden.

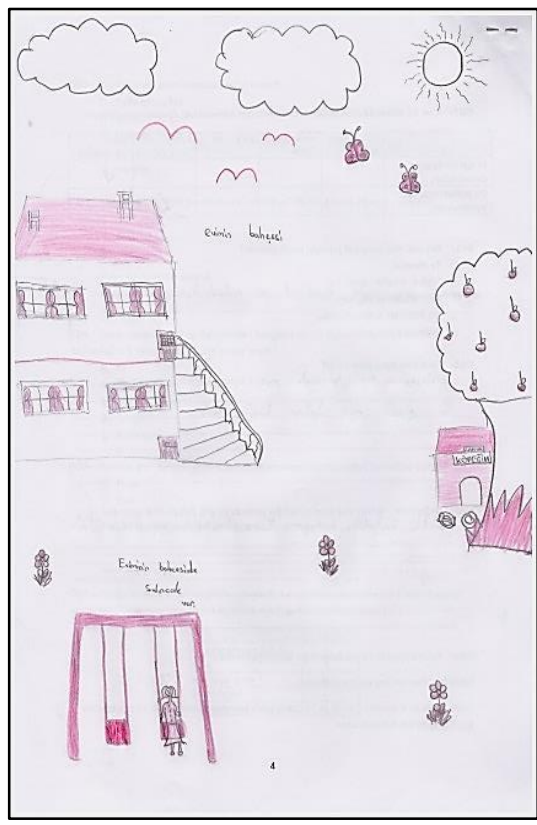

(a)

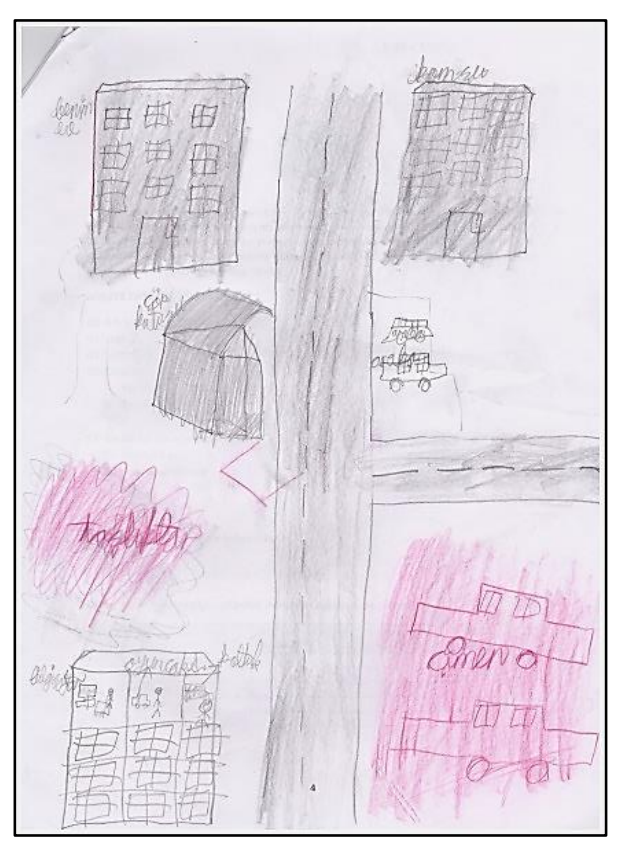

(b)

Fig. 2. Children's Drawings, (a) Rural (b) Urban

Table 6. Urban Image Items Drawn in the Pictures

\begin{tabular}{|c|c|c|c|c|}
\hline \multirow{2}{*}{ Image Items } & \multicolumn{2}{|c|}{ Rural } & \multicolumn{2}{c|}{ Urban } \\
\cline { 2 - 5 } & $\begin{array}{c}\text { Number Of } \\
\text { Drawing }\end{array}$ & $\%$ & $\begin{array}{c}\text { Number Of } \\
\text { Drawing }\end{array}$ & $\%$ \\
\hline Paths & 3 & 12 & 16 & 64 \\
\hline Edges & 1 & 4 & 6 & 24 \\
\hline Districts & 2 & 8 & 7 & 28 \\
\hline Nodes & 0 & 0 & 3 & 12 \\
\hline Total & 25 & 100 & 25 & 100 \\
\hline
\end{tabular}

Cities' being subdivided and functionally regionalized can be said to be the reason for the fact that paths, edges, districts, and nodes were frequently drawn in the pictures of the children from urban areas. 
Table 7. Urban Signs Drawn in the Pictures

\begin{tabular}{|c|c|c|c|c|}
\hline \multirow{2}{*}{ Urban Signs } & \multicolumn{2}{|c|}{ Rural } & \multicolumn{2}{c|}{ Urban } \\
\cline { 2 - 5 } & $\begin{array}{c}\text { Number Of } \\
\text { Drawing }\end{array}$ & $\%$ & $\begin{array}{c}\text { Number Of } \\
\text { Drawing }\end{array}$ & $\%$ \\
\hline Car & 3 & 12 & 19 & 76 \\
\hline Traffic Signs & 0 & 0 & 2 & 8 \\
\hline High Buildings & 0 & 0 & 7 & 28 \\
\hline Construction & 0 & 0 & 1 & 4 \\
\hline Total & 25 & 100 & 25 & 100 \\
\hline
\end{tabular}

While only $12 \%$ of the children who lived in the rural areas drew cars, $76 \%$ of the children who lived in the urban areas did so. There were signal elements such as traffic signs, high buildings, and construction only in the pictures of the children from cities. This could be due to the fact that children's perception of playing fields is affected by the dense structuring and traffic jams.

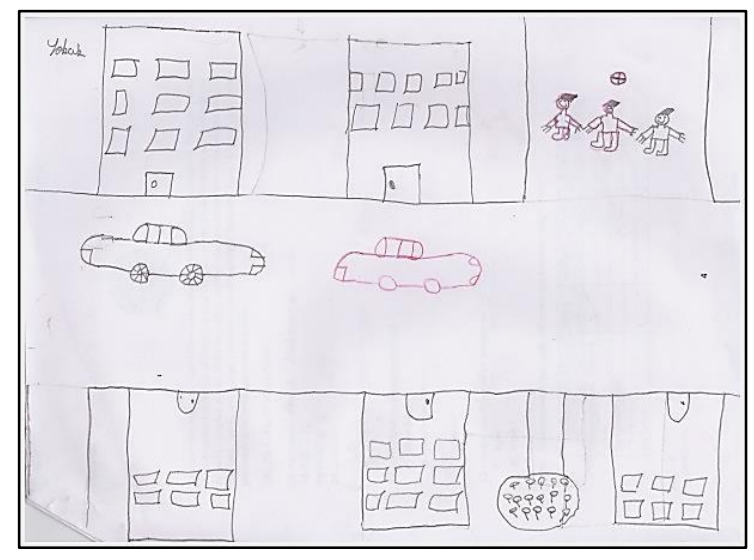

(a)

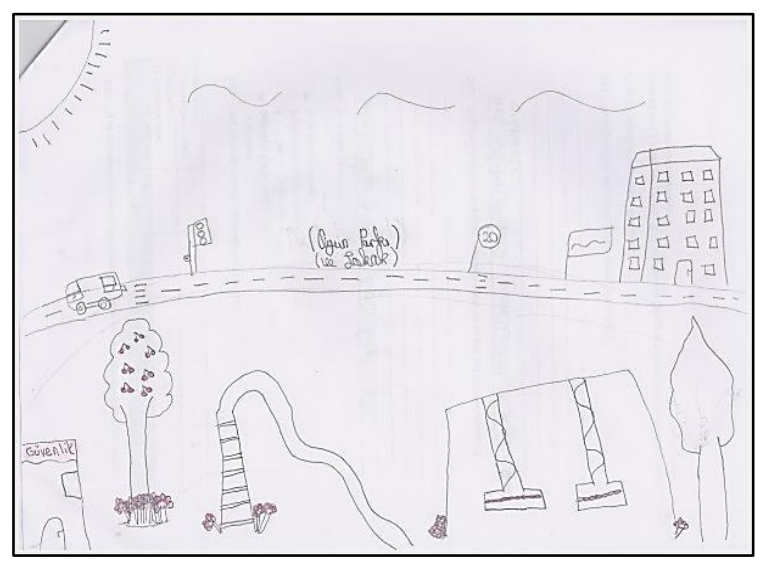

(b)

Fig. 3. Children's Drawings, (a) Urban (b) Urban

\section{CONCLUSION AND RECOMMENDATIONS}

The results of this research indicate that children mostly use such outdoor places as playgrounds, streets, and gardens of their houses as playing fields. It has also been found that children in urban areas are worried about the negative aspects of cities, such as people with bad intentions, cars, construction work, and being kidnapped. Today, children in cities have fewer opportunities to play outside than children in the countryside, and their use of outdoor spaces for games is limited because of safety concerns. It has been determined that children who live in rural areas have the advantage of having gardens attached to their houses, thanks to which they can play safely. It has been observed that children's perceptions of playing fields are affected by the advantages and disadvantages of the environment that they live in, and this is reflected in their drawings.

While there were urban sign items, such as traffic signs, high-rise buildings, and construction areas in the drawings of children of urban areas, there were none of these signs in the pictures of children from the countryside. It has been found that, children's space imagery changes according to the different stimuli provided by their environment.

Children need enough time and a suitable environment for their developmental stages to discover and develop themselves. Safe and free places for playing games should be offered to children, as these places are important for their physical, cognitive, and emotional development. Children have the opportunity to gain perceptive, physical, and emotional acquisitions from the places where they feel they belong and that support their developmental stages, which enables them to discover both themselves and their environments, and thus meet all their needs. They can play independently in these fields with their friends and acquire social skills.

What children experience in the environment that they inhabit during their childhood forms the basis for the perceptions that they will have in the future. Opportunities, security, or concerns about their playing fields 
affect children's view of life. Therefore, children's playing fields should be designed in a way that is suitable for their developmental stage and that gives them the opportunity to play safely. Consequently, they will have the chance to complete their physical, psychological, and mental developments by freely playing outside without the company of an adult or any limitations.

Studies that have been conducted to create more opportunities for children to play games in other countries should be analyzed, and they can be applied in our country. Academicians, pedagogues, and local authorities should work together toward this aim, and children-friendly cities should be built. In this way, we can contribute to raising healthy, socially adaptable, happy, and successful individuals, by creating more opportunities for children to play outside.

\section{REFERENCE LIST}

Abu-Gazzeh, T. M. (1998). Children Use of Streets as a Playground in Abu-Nusseir, Jordan. Environment and Behavior, 30(6), 799-831.

Appleyard, D. (1970). Styles and Methods of Structuring a City. Environment and Behavior, 2, 100-117.

Ciravoğlu, A. (2004). Çocuk Mekanlarını Tasarlamak: Ana ve İlköğretim Okulları. Mimarist, 11, 38-39.

Çanakçıoğlu, N. G. (2012). Çocukta Mekan Algısının Gelişimi ve Mekansal İmge Zenginliği Bakımından Malzemenin Önemi, Mimarlıkta Malzeme, 22, 74-81.

Duman, G. \& Koçak, N. (2013). Çocuk Oyun Alanlarının Biçimsel Özellikleri Açısından Değerlendirilmesi: Konya Illi Örneği. Türk Eğitim Bilimleri Dergisi, 11(1), 64-81.

Erkman, U. (1982). Mimari Tasarım İçin Bir Veri Üretim Yöntemi Olarak Çevre Analizi. İstanbul: ITÜ Matbaası.

Erkonak Aydemir, S. (2004). Kentsel Açık ve Yeşil Alanlar "Rekreasyon". Kentsel Alanların Planlanması ve Tasarımı (285-337). Trabzon: Akademi Kitabevi.

Ertürk, S. (1992). Çocuk ve Mekan. İ. Altan, (ed.), Mimarlık ve Şehircilikte Mekan (22-24). İstanbul: Sistem Yayıncılık.

Koçyiğit, S., Tuğluk, M. N. \& Kök, M. (2007). Çocuğun Gelişim Sürecinde Eğitsel Bir Etkinlik Olarak Oyun. Kazım Karabekir Eğitim Fakültesi Dergisi, 16, 324-342.

Lynch, K. (2013). Kent Imgesi (İ. Başaran, Trans.) İstanbul: Kültür Yayınları. (Original work published 1960)

Öymen Gür, Ş. \& Zorlu, T. (2002). Çocuk Mekanları. İstanbul: YEM Yayınları.

Piaget, J. \& Inhelder, B. (1956). The Child's Conception of Space. Londra: Roudledge and Kegan Paul

Rivkin, M. (1997). The Schoolyard Habitat Movement: What It Is and Why Children Need It. Early Childhood Education Journal, 25 (1), 61-67.

Şahin, K. (1984). Çocuğun Yasaklı Mekanı Üzerine Notlar. Mimarlık, 9, 24-27.

Tandon, P. S., Zhou C. \& Christakis, D. A. (2012). Frequency of Parent-supervised Outdoor Play of US Preschool-aged Children. Archives of Pediatrics and Adolescent Medicines. 166(8), 707-712.

Uluğ Ormanlığlu, M. (2013). Niçin Oyun? Çocuğun Gelişiminde ve Çocuğu Tanımada Oyunun Önemi. İstanbul: İdeal Kültür Yayıncılık.

Ünlü, A. (1998). Çevresel Tasarımda İlk Kavramlar. İstanbul: ITÜ Mimarlık Fakültesi Baskı Atölyesi.

Volkan Aksu, Ö. \& Demirel, Ö. (2011). Trabzon Kenti İlköğretim Okul Bahçelerinde Tasarım ve Alan Kullanımları. SDÜ Orman Fakültesi Dergisi, 12, 40-46.

White, R. \& Stoecklin, V. (1998). Children's outdoor play and learning environments: Returning to nature. Early Childhood News Magazine. https://www.whitehutchinson.com/children/articles/outdoor.shtml.( Accessed: 08.12.2015).

Yavuzer, H. (2015). Çocuk Psikolojisi (38th edition). İstanbul: Remzi Kitabevi.

Yavuzer, H. (2015). Resimleriyle Çocuk (19th edition). İstanbul: Remzi Kitabevi.

Yılmaz, S., \& Bulut, Z. (2002). Kentsel Mekanlarda Çocuk Oyun Alanları Planlama ve Tasarım İlkeleri. Atatürk Üniversitesi Ziraat Fakültesi Dergisi, 33(3), 345-351. 